\title{
Zoonoses in humans from small rural properties in Jataizinho, Parana, Brazil
}

\author{
Daniela Dib Gonçalves ${ }^{1}$, Aline Benitez ${ }^{1}$, Fabiana Maria Ruiz Lopes-Mori ${ }^{1}$, \\ Lucimara Aparecida Alves ${ }^{1}$, Roberta Lemos Freire ${ }^{1}$, Italmar Teodorico Navarro ${ }^{1}$, \\ Maria Aparecida Zanella Santana ${ }^{3}$, Luís Roberto Alves dos Santos ${ }^{3}$, Teresa Carreira ${ }^{2}$, \\ Maria Luísa Vieira ${ }^{2}$, Julio Cesar de Freitas ${ }^{1}$ \\ ${ }^{1}$ Programa de Pós-Graduação em Ciência Animal, Departamento de Medicina Veterinária Preventiva, \\ Universidade Estadual de Londrina, Londrina, PR, Brazil. \\ ${ }^{2}$ Grupo de Leptospirose e Borreliose de Lyme, Unidade de Microbiologia Médica, Instituto de Higiene e \\ Medicina Tropical, Centro de Recursos Microbiológicos, Universidade Nova de Lisboa, Lisboa, Portugal. \\ ${ }^{3}$ Unidade Básica de Saúde de Jataizinho, Jataizinho, PR, Brazil.
}

Submitted: May 20, 2011; Approved: July 2, 2012.

\begin{abstract}
The aim of this study was to conduct a serological survey for Lyme diseases, brucellosis, leptospirosis and toxoplasmosis and identify the risk variables related to these zoonoses in humans living in the rural area of Jataizinho, state of Parana, Brazil. A total of 63 rural properties were surveyed. Additionally, 207 serum samples collected from these rural area inhabitants were tested for indirect immunofluorescence (IFI) and western blots (WB) were performed to detect Borrelia burgdorferi (sensu lato); a tamponated acidified antigen test (AAT) and 2-mercaptoethanol (2-ME) were used to detect antibodies of Brucella abortus; the microscopic agglutination test (MAT) was carried out to detect antibodies anti-Leptospira spp. and IFI was used to find antibodies of Toxoplasma gondii. Two of the samples $(0.96 \%)$ were reactive for Lyme borreliosis, three (1.4\%) for brucellosis, $25(12.1 \%)$ for leptospirosis and $143(69.1 \%)$ for toxoplasmosis. Although the town of Jataizinho has a human development index (IDH) that was considered to be average (0.733) in the state of Parana, the low social, economic and cultural conditions of the population from small rural properties have resulted in lack of basic information on animal health and direct or indirect contact with the various species of domestic animals, wildlife and ticks have probably contributed to the prevalence levels found. These results show the need for additional regional studies in order to determine the epidemiological characteristics of these diseases as well as their respective vectors and reservoirs so that effective prophylaxis can be administered in the human population.
\end{abstract}

Key words: Lyme disease, leptospirosis, brucellosis, toxoplasmosis, human, antibody.

\section{Introduction}

Leptospirosis, brucellosis and toxoplasmosis are widely distributed zoonoses. Domestic and wild animals act as reservoirs for the etiological agents for these diseases. For Lyme disease, tick acts as a vector for the etiological agent and human beings and as accidental hosts in the epidemiological cycle (Gill and Johnson, 1992; Macedo, 1997; Corradi et al., 2005; Langoni et al., 2008).
Seroepidemiological studies have described these zoonoses in human populations from different rural areas in Brazil. They have shown the importance of adopting preventive measures for residents exposed to infections (Garcia and Navarro, 2001; Gonçalves et al., 2006; Naka et al., 2008). In rural workers, infections become more frequent due to either absence or inappropriate use of protective equipment (Schwabe, 1984; Gonçalves et al., 2006).

The town of Jataizinho, located in the northern region of Paraná, has a total area of $201.847 \mathrm{~km}^{2}$, with a humid

Send correspondence to J.C. Freitas. Departamento de Medicina Veterinária Preventiva, Centro de Ciências Agrárias, Universidade Estadual de Londrina, 86051-990 Londrina, PR, Brazil. E-mail: freitasj@uel.br. 
subtropical climate and is bordered, by the Tibagi River. According to the 2007 report from the basic health unit (BHU), its population was estimated at 11,604 inhabitants, with 1,850 residents in rural areas. This city has a human development index (HDI) of 0.733 according to PNUD (2010) that is considered as average in the state of Parana. However, the population in small rural properties faces lower social, economic and cultural conditions.

According to data from the BHU that was collected in 2009 in Jataizinho, there has been no diagnosis of brucellosis, leptospirosis or toxoplasmosis in the human population since 2003 (Gonçalves et al., 2006). In contrast, the incidence of Lyme borreliosis has never been investigated. The aim of this study was to perform a seroepidemiological survey in residents from rural areas of Jataizinho and identify variables associated with these four zoonoses.

\section{Materials and Methods}

\section{Samples, collection sites and conduction of tests}

This research was approved by the Committee of Ethics in Research involving Humans from the Universidade Estadual de Londrina (UEL) (No. 319/06). According to data from the town under study, which was provided by the National Institute of Colonization and Agrarian Reform (INCRA), 95 out of 127 properties in the town of Jataizinho, Paraná state, were characterized as small, but only owners from 63 agreed to participate in this project. From February to November 2007, blood samples were collected voluntarily, from all 207 persons who were between 15 and 72 years old living in the 63 small rural properties. Serological tests were performed in laboratories at the Department of Preventive Veterinary Medicine (DMVP) at UEL and the Leptospirosis and Lyme Borreliosis laboratory at the Institute of Hygiene and Tropical Medicine (IHMT), New University of Lisbon (UNL).

\section{Laboratory tests}

Sera were screened for antibodies against Borrelia burgdorferi from the complex sensu lato (s.l.) by indirect immunofluorescence (IFI), glass slides coated with immobilized spirochetes (antigen) from the reference strain (B31) from B. burgdorferi sensu stricto (s.s.) were used (Collares-Pereira et al., 2000). The results were subsequently confirmed by western blots (WB) using the following commercial kits "recom Line Borrelia IgM" and "recom Line Borrelia IgG" (Mikrogen ${ }^{\circledR}$, Germany). Highly purified recombinant B. burgdorferi s.s., B. afzelii, $B$. garinii and $B$. spielmanii antigens were used in the western blotting procedure (Camargo et al., 1995; Garcia et al., 1999b). In IFI, sera presenting Borrelia with titers $\geq 256$ were considered positive, and the results of antigenic fractions (p100, VlsE, p58, p41, p39, OspA, OspC and P18) were performed according to the manufacturer's instructions.
To detect antibodies against Brucella spp., sera were subjected to screening using the tamponated acidified antigen test (AAT), and positive results were confirmed with a 2-mercaptoethanol (2-ME) test (Technology Institute of Paraná-Tecpar) (Alton et al., 1976). In AAT, positive samples were defined as samples presenting macroscopic agglutination. In 2-ME, positive samples formed a precipitate with a film at the bottom of the tube and a clear supernatant. Samples that had signs of Brucella spp. in both serological tests were considered to be positive.

For the detection of anti-Leptospira spp. antibodies, sera were subjected to the microscopic agglutination test (MAT) with 22 reference serovars (Myers, 1985). Serum samples that presented at least $50 \%$ of leptospires agglutinated in a 1:100 dilution were considered to be positive. These samples were further diluted to determine maximum positive dilution. In the analysis of the results, the more probable serovars had the highest agglutination. Those presenting co-agglutination in the highest dilution were considered to be positive for Leptospira spp (Myers, 1985).

To detect anti-Toxoplasma gondii antibodies, sera were subjected to an indirect immunofluorescence assay (IFI) (Camargo, 1973), using a commercial conjugate (an anti-human immunoglobulin $G$ fluorescein-labeledSigma $^{\circledR}$, USA). Sera were tested in serial dilutions until a dilution of 1:4,096 was reached, and the samples presenting fluorescent tachyzoites with a titer $\geq 16$ were considered to be positive.

\section{Epidemiological research}

To obtain epidemiological information, each human person individually answered a questionnaire that included information on variables related to the zoonoses studied (education level; presence of dog and/or cat in the property; presence of other species of domestic or wild animals in the property, presence and control of rodents in the property; whether the person aids and/or performs bovine castrations, assists in delivering animals on artificial insemination or culling of animals; daily work with animals; ingestion of raw milk or raw meat; eating vegetables without washing; habit of walking barefoot; use of personal protective equipment; ticks attached to the body; ticks in the house; flu outbreak up to 15 days before collection; and, reports of joint pain and night sweats).

\section{Statistical analysis}

The results were statistically analyzed with a chisquare $\left(\chi^{2}\right)$ correction using Yates or Fisher's exact test. Tabulation of epidemiological data and analyses was performed using the EpiInfo statistical program version 6.04 (CDC) with a 5\% significance level. As an association measure, odds ratio (OR) calculation was used with confidence interval of 95\% (Dean et al., 1994).

Registration of rural properties for research of epidemiological occurrences was done through a global posi- 
tioning system (GPS). A global positioning system was used in this study, and the geo-processing package ArcGIS 9.3 -ESRI was later used to map the resident properties that were studied as to the different zoonoses considered.

\section{Results}

For Lyme disease, a total of $18(8.7 \%)$ serum samples were positive in IFI, but only two $(0.96 \%)$ presented IgM reactivity for Borrelia garinii and B. burgdorferi s.s. in a western blot (Figure 1). For brucellosis, three samples $(1.4 \%)$ were considered positive in $2-\mathrm{ME}$ test with titers of $1: 50$ each.

Analysis of variables associated with anti-Borrelia burgdorferi s.l. and anti-Brucella abortus antibodies is shown in Table 1.

For leptospirosis, a total of 25 (12.1\%) samples were considered to be reactive in MAT. From these samples, 11 $(44 \%)$ had antibodies for one serotype, three (27.3\%) samples were positive for Hardjo serovar, three (27.3\%) for Castellonis, two (18.2\%) for Grippotyphosa and for Australis, Pomona and Shermani one sample (9.1\%) each. There were titers ranging between 100 and 1,600 for all samples. In 14 (56\%) samples, antibodies against two serotypes were simultaneously detected with titers between $1: 100$ and 1:200, which made it impossible to characterize the most likely serovar. The analysis of the variables associated with the presence anti-Leptospira antibodies is shown in Table 2.

For toxoplasmosis, 143 (69\%) samples were considered to be reactive, with titers between 16 and 4,096. There
Table 1 - Variables associated with the presence of anti-Borrelia burgdorferi s.1. and anti-Brucella abortus antibodies in 207 human sera samples from people of the rural area in the state of Parana, Brazil, 2007.

\begin{tabular}{|c|c|c|c|}
\hline Disease & Positive samples & $\mathrm{p}$ & OR (CI 95\%) \\
\hline Variables & Total $(\%)$ & & \\
\hline \multicolumn{4}{|c|}{ Lyme disease } \\
\hline \multicolumn{4}{|c|}{ Ticks attached to body } \\
\hline Yes & $02 / 16(12.5)$ & $0.0056 *$ & \\
\hline No & $00 / 191(0.0)$ & & \\
\hline \multicolumn{4}{|c|}{ Ticks in the house } \\
\hline Yes & $02 / 27(7.4)$ & $0.0164 *$ & \\
\hline No & $00 / 180(0.0)$ & & \\
\hline \multicolumn{4}{|c|}{ Brucellosis } \\
\hline \multicolumn{4}{|c|}{ Performing artificial insemination } \\
\hline Yes & $02 / 13(15.0)$ & $0.0105 *$ & \\
\hline No & 01/194 (51.0) & & \\
\hline \multicolumn{4}{|c|}{ Joint pain and night sweats } \\
\hline Yes & 03/07 (42.8) & $0.0001 *$ & \\
\hline No & $00 / 200(0.0)$ & & \\
\hline
\end{tabular}

$\mathrm{p}=$ probability ${ }^{*}$ Fisher's exact test $\mathrm{OR}=$ Odds ratio $\mathrm{CI}=$ confidence interval.

were no statistically significant differences between these variables and infection by $T$. gondii.

In $59(93.7 \%)$ properties, positive results for the zoonoses were found. Also, in 37 (62.7\%) properties, a single infection was observed; there was a single infection $(2.7 \%)$ for leptospirosis and 36 (97.3\%) for toxoplasmosis. Mixed infections were also observed at 22 properties: one property
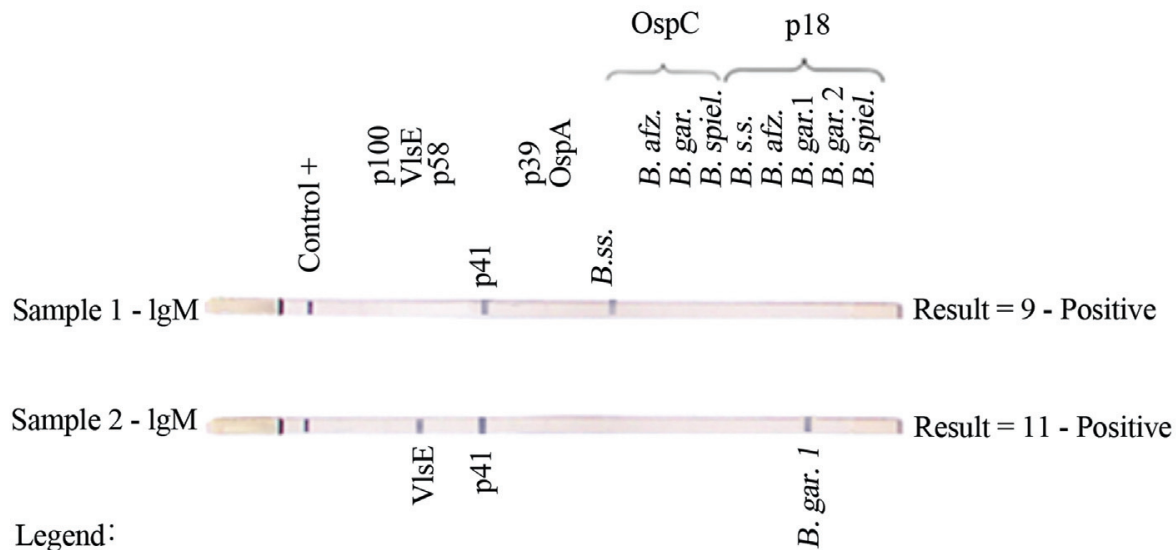

\begin{tabular}{lll} 
Legend: & \multicolumn{1}{c}{ OspC } & \multicolumn{1}{c}{$\mathrm{p} 18$} \\
& & \multicolumn{1}{c}{} \\
p100 $=5$ & B. sensu strito $=8$ & B. sensu strito $=5$ \\
V1sE $=5$ & B. afzelli $=8$ & B. afzelli $=5$ \\
p58 $=4$ & B. garinii $=8$ & B. garinii $1=5$ \\
p41 $=1$ & B. spielmanii $=8$ & B. garinii $2=5$ \\
p49 $=4$ & & B. spielmanii $=5$ \\
OspA $=5$ & &
\end{tabular}

Figure 1 - Western blot positive for IgM in serum samples from two asymptomatic humans for Borrelia burgdorferi s.1. The subjects were from the rural area of Jataizinho in the state of Parana, Brazil. 
Table 2 - Variables associated with the presence of anti-Leptospira antibodies in 207 humans sera samples from the rural area of Jataizinho in the state of Parana, Brazil.

\begin{tabular}{|c|c|c|c|}
\hline Variables & $\begin{array}{c}\text { Positive samples } \\
\text { Total (\%) }\end{array}$ & $\mathrm{p}$ & OR (CI 95\%) \\
\hline \multicolumn{4}{|c|}{ Education level $^{\circ}$} \\
\hline Literate & $11 / 170(6.47)$ & $0.0001 *$ & $0.11(0.04-0.31)$ \\
\hline Illiterate & $14 / 37(37.00)$ & & \\
\hline \multicolumn{4}{|c|}{ Control of rodents on the property ${ }^{* *_{\mathrm{o}}}$} \\
\hline Yes & $02 / 78(2.56)$ & 0.0138 & $0.11(0.02$ to 0.52$)$ \\
\hline No & 23/121 (19.0) & & \\
\hline \multicolumn{4}{|c|}{ Assistance in animal deliveries } \\
\hline Yes & $21 / 74(28.3)$ & 0.0001 & $12.78(3.89-46.38)$ \\
\hline No & $04 / 133(3.0)$ & & \\
\hline \multicolumn{4}{|c|}{ Practice of castrating animals ${ }^{* * *}$} \\
\hline Yes & $18 / 49(36.7)$ & 0.0001 & $18.73(5.43-70.97)$ \\
\hline No & $04 / 133(3.0)$ & & \\
\hline \multicolumn{4}{|c|}{ Slaughtering of animals } \\
\hline Yes & 23/110 (20.9) & 0.0001 & $12.56(2.75-79.47)$ \\
\hline No & 02/97 (2.1) & & \\
\hline \multicolumn{4}{|c|}{ Daily work with animals } \\
\hline Yes & $21 / 110(19.0)$ & 0.0020 & $5.49(1.69-19.71)$ \\
\hline No & 04/97 (4.1) & & \\
\hline \multicolumn{4}{|c|}{ Flu outbreak up to 15 days prior to collection } \\
\hline Yes & 20/21 (95.0) & $0.0001 *$ & $724.0(73.65-17781.32)$ \\
\hline No & $05 / 186(2.7)$ & & \\
\hline
\end{tabular}

$\mathrm{p}=$ probability OR $=$ Odds Ratio $\mathrm{CI}=$ Confidence interval.

$*=$ Fisher's exact test.

** = Question not answered by eight rural residents

$* * *=$ Question not answered by 25 rural residents.

${ }^{\circ}=$ Protective factors.

each $(4.5 \%)$ for Lyme disease and toxoplasmosis; one property each (4.5\%) for Lyme disease, leptospirosis and toxoplasmosis; three properties $(13.6 \%)$ for brucellosis and toxoplasmosis; and 17 properties $(77.2 \%)$ for leptospirosis and toxoplasmosis (Figure 2).

\section{Discussion}

Different researchers have demonstrated the presence of antibodies and variations in clinical manifestations for the zoonoses in different regions of Brazil to understand the occurrence of Lyme disease(Yshikawa, 1996; Costa et al., 2001; Yoshinari et al., 2007; Naka et al., 2008). In the state of Parana, this was the first detection of antibodies against B. burgdorferi s.l. in rural area residents who were directly or indirectly exposed to domestic or wild animals and ticks, the latter being considered vectors for Borrelia spp (Bennett, 1995).

In this study, 18 positive serum samples were found in IFI, and after using a screening test for the disease, only

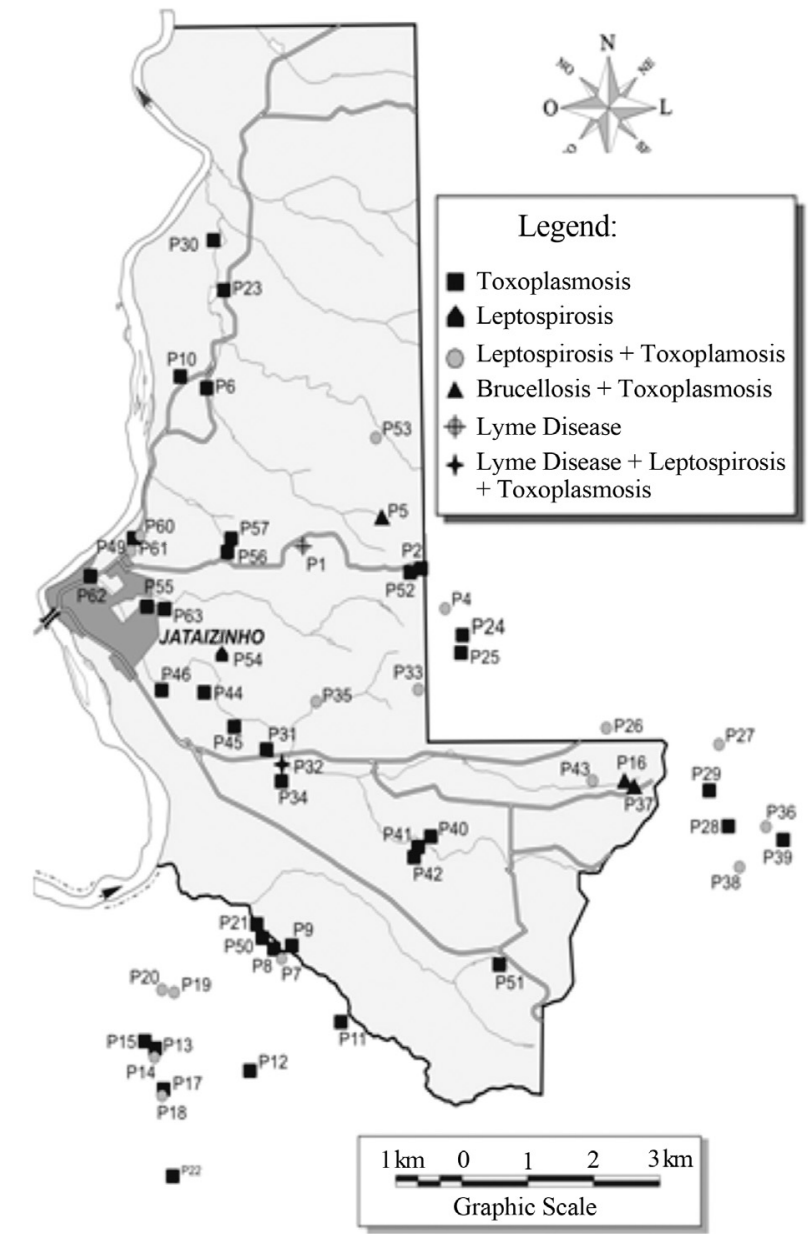

Figure 2 - Map of the rural area in Jataizinho (PR) indicating the properties with reactive humans for the various zoonoses surveyed, Parana, 2007.

two $(0.96 \%)$ samples were confirmed by a western blot. This test was performed according to the criteria establish by Center for Disease Control and Prevention (CDC) (Yoshinari et al., 2003) and by the criteria for European Borrelia species (Hauser et al., 1999) for having identified specific proteins for $B$. burgdorferi s.s. and B. garinii, respectively. In Brazil, the presence of anti-B. burgdorferi s.s. antibodies in symptomatic patients with history of contact with ticks has been demonstrated by western blot (Yoshinari et al., 2003). In another study, using ELISA, anti- $B$. garinii antibodies were detected in patients with facial paralysis (Pirana et al., 2000). In the present study, the main risk variables found were the ticks attached to the body $(p=0.0056)$ and their presence indoors $(p=0.0164)$, which was consistent with other studies that have reported cases of Lyme disease in humans Yoshinari et al., 2007.

In Brazil, despite the high geographical distribution of both invertebrate and vertebrate hosts for Borrelia spp., there are few descriptions of these spirochetes. As such, further serological and molecular studies are necessary whether in humans or in different species of domestic and 
wild animals and particularly in ixodid ticks, in order to better understand the disease.

Bovine brucellosis is a disease endemic to many regions of the world, and the cases diagnosed in humans are almost always associated with direct contact with infected animals or their contaminated products (Gómez et al., 2008). In this study, a prevalence of $1.4 \%$ for brucellosis in rural residents was lower than the results found in the states of Pernambuco and Tocantins, where prevalence values were $21.1 \%$ and $8.1 \%$, respectively (Moura et al., 2000; Ramos et al., 2008). This low prevalence of human brucellosis among rural residents in Jataizinho was probably related to the low prevalence (3\%) of bovine brucellosis in the state of Parana (Dias, 2004).

The main risk of infection by $B$. abortus in humans was related to environmental contamination from abortion products (Wray, 1975). In this research, it was found that owners of small rural properties did not have basic information on animal health, especially bovine brucellosis, and those owners failed to evaluate the consequences of these risks to human health when purchasing an animal infected with B. abortus. Serological positive results for brucellosis in three residents showed a relationship to their occupation. The positive results were likely due to the individuals direct contact with infected vaginal secretions, performance of artificial insemination and lack or inadequate use of protective equipment. This finding suggests the need for developing an educational program designed to raise awareness about the health of animal herds. Additionally, there should be periodic serological monitoring of these animals as well as education on sanitary measures and individual protection for populations that are at risk of infection.

In humans, brucellosis appears as a chronic disease with symptoms of fever, night sweats, joint pain and myalgia (Ferreira et al., 2002; Ramos et al., 2008). These symptoms are compatible with the present results, as night sweats and joint pain $(p=0.0001)$ were found in three humans that had positive results in the 2-ME test.

In the human population studied from the rural area of Jataizinho, the prevalence of leptospirosis $(12 \%)$ was similar to the prevalence found in the state of Rondônia (10\%) and lower than the prevalence found in the state of São Paulo (23.5\%) (Myers, 1985; Aguiar et al., 2007). These results may have been influenced by differences in the prevalence of animal leptospirosis from corresponding Brazilian states and differences in the study periods. Therefore, there may have been higher or lower odds of infection in humans who came into contact with urine, organs, viscera and secretions from infected animals.

The risk variables found by this study included aiding with animal deliveries $(p=0.0001)$, castrating animals $(p=0.0001)$, slaughtering animals $(p=0.0001)$, and daily contact with animals $(\mathrm{p}=0.0020)$. These results were consistent with those obtained in the states of Piaui (Macedo, 1997) and Parana (Garcia et al., 1999a), which have also re- ported that occupational exposure is linked to work activities in rural areas. The association with occupational activities identified in this study can be attributed not only to close and continuous contact with different species of infected animals, such as cattle, horses, dogs and wild animals, but also work activities associated with wetlands as well as agricultural and livestock structures contaminated with urine from infected rodents or other animal species.

In humans, leptospirosis may cause serious illnesses or only sub-clinical infections, which is similar to the difference between the flu and colds (Gonçalves et al., 2006); similar to the variable detected in this study, flu outbreak up to 15 days before blood collection $(\mathrm{p}=0.0001)$ in surveyed residents.

The prevalence of $69 \%$ for toxoplasmosis was similar to other studies, which were also conducted in the state of Parana with prevalences of $66 \%$ and $83 \%$, respectively (Garcia et al., 1999a; 1999b).

Despite the high prevalence found in the humans studied, there was no association between the variables that were analyzed and the presence of anti-T. gondii antibodies. The high prevalence in rural areas may be due to greater exposure of this population to an environment where there is more contamination by oocysts or domestic cats. This result demonstrates that the inhabitants of this town were exposed to common sources of infection regardless of gender, age, activities or eating habits. Another study in the state of Parana found a prevalence of $71 \%$, and the authors were not able to identify variables associated with this zoonotic disease in rural area residents (Garcia and Navarro, 1995). Other authors considered consumption of food and/or water contaminated with sporulated oocysts as well as, ingestion of raw or undercooked meat and sausages containing tissue cysts of $T$. gondii as the main sources of disease transmission to humans (Avelino et al., 2004; Dubey et al., 2005).

Even though the town of Jataizinho has a human development index (HDI) that is considered to be average (0.733) in the state of Parana (PNUD, 2010), the low social, economic and cultural conditions of the population in small rural properties could be associated with both the lack of basic information on animal health and the direct or indirect contact with the various species of domestic and wild animals as well as ticks. It is likely that these factors contributed to the prevalence levels that were found. These results show the need for regional studies to determine the epidemiological characteristics of these four diseases as well as their respective vectors and reservoirs. The ultimate goal of these studies would be to develop effective prophylaxis for the human population.

\section{Acknowledgments}

We would like to acknowledge the CAPES (Coordenação de Aperfeiçoamento de Pessoal de Nível Superior) and SETI/UFG (Secretaria do Estado da Ciência e Tecno- 
logia do Ensino Superior do Estado do Paraná/Unidade Gestora Fundo Paraná). Additionally, we would like to thank the Basic Health Unit of Jataizinho, Paraná, for their help as well as Cleonice Regis and José Neto Soares Filho from the Universidade Nova de Lisboa (UNL) for preparing the digital mapping.

\section{References}

Aguiar DM, Cavalcante GT, Camargo LMA, Labruna MB, Vasconcellos SA, Souza GO, Gennari SM (2007) AntiLeptospira spp and anti-Brucella spp antibodies in human from rural area of Monte Negro municipality state of Rondônia, Brazilian Western Amazon. Braz J Microbiol 38:93-96.

Alton GG, Jones LM, Pietz DE (1976) Las Técnicas de Laboratorios en la Brucellosis. Organización Mundial de la Salud, Ginebra, 173 pp.

Avelino MM, Campos-Júnior D, Parada JB, Castro AM (2004) Risk factors for Toxoplasma gondii infection in women of childbearing age. Braz J Infect Dis 8:164-174.

Bennett CE (1995) Ticks and Lyme disease. Adv Parasitol 36:343-405.

Camargo ME (1973) Introdução às técnicas Imunofluorescência. Rev Bras Patol Clinica 10:143-171.

Camargo MCV, Antunes CM, Chiari CA (1995) Epidemiologia da infecção por Toxoplasma gondii no município de Ribeirão das Neves, MG: I - Importância dos animais domésticos como fonte de infecção do Toxoplasma gondii para o homem. Rev Soc Bras Med Trop 28:211-214.

Collares-Pereira M, Santos SC, Vieira ML (2000) Valor diagnóstico da técnica de imunofluorescência indireta com diferentes estirpes no rastreio da Borreliose de Lyme. Trab Soc Port Dermatol Venereol 58:97-105.

Corradi DA, Carvalho VM, Coutinho SD (2005) Anticorpos para Borrelia burgdorferi em indivíduos que trabalham com animais silvestres. Arq Bras Med Vet Zoot 58:966-968.

Costa IP, Bonoldi VLN, Yoshinari NH (2001) Perfil clínico e laboratorial da doenca de Lyme-Simile no estado de Mato Grosso do Sul: Análise de 16 pacientes. Rev Bras Reumatol 41:142-150.

Dean AG, Dean JA, Coulombier D, Brendel KA, Smith DC, Burton AH, Dicker RC, Sulivan KM, Fagan RF, Arner TG (1994) Epi Info, ver. 6: A word processing, database, and statistic program for epidemiology on microcomputers. Center for Diseases Control and Prevention, Atlanta.

Dias JA (2004) Prevalência e Distribuição Geográfica da Brucelose Bovina e Bubalina no Estado do Paraná, Brasil. M.Sc. Dissertation, Universidade Estadual de Londrina.

Dubey JP, Hill DE, Jones JL, Hightower AW, Kirkland E, Roberts JM, Marcet PL, Lehmann T, Vianna MCB, Miska K, Sreekumar C, Kwok OCH, Shen SK, Gamble HR (2005) Prevalence of viable Toxoplasma gondii in beef, chicken, and pork from retail meat stores in the United States and risk assesment to consumers. J Parasitol 91:1082-1093.

Ferreira CR, Ferreira CR, Tatagiba TA, Souto Filho JTD (2002) Espondilodiscite brucelósica: Relato de caso. Rev Soc Bras Med Trop 35:255-258.

Garcia JL, Navarro IT (1995) Levantamento soroepidemiológico da toxoplasmose em moradores da zona rural do município de Guaraci, Paraná, Brasil. Semina 16:63-67.
Garcia JL, Navarro IT (2001) Avaliação sorológica da leptospirose e brucelose em pacientes moradores da área rural do município de Guaraci, Paraná, Brasil. Rev Soc Bras Med Trop 34:299-300.

Garcia JL, Navarro IT, Ogawa L, Oliveira RC (1999a) Soroprevalência do Toxoplasma gondii em suínos, bovinos, ovinos e equinos e sua correlação com humanos, felinos e caninos, oriundos de propriedades rurais do norte do Paraná, Brasil. Ciência Rural 29:91-97.

Garcia JL, Navarro IT, Ogawa L, Oliveira RC, Garcia SMF, Leote J (1999b) Soroepidemiologia da toxoplasmose e avaliação ocular pela Tela de Amsler, em pacientes da zona rural, atendidos pela unidade de saúde do município de Jaguapitã, PR, Brasil. Rev Soc Bras Med Trop 32:671-676.

Gill SJ, Johnson RC (1992) Immunologic methods for the diagnosis of infections by Borrelia burgdorferi (Lyme Disease). In: Rose RN, De Macario EC, Fahey JL, Friedman H, Penn GM (eds) Manual of Clinical Laboratory Immunology. 4th edition. ASM Press, Washington DC, pp 452-458.

Gómez MC, Nieto JA, Rosa C, Geijo P, Escribano MA, Munõz A, López C (2008) Evaluation of seven tests for diagnosis of human brucellosis in an area where the disease is endemic. Clin Vaccine Immunol 15:1031-1033.

Gonçalves DD, Telez PS, Reis CR, Lopes FMR, Freire RL, Navarro IT, Alves LA, Muller EE, Freitas JC (2006) Seroepidemiology and occupational and enviromental variables for leptospirosis, brucellosis and toxoplasmosis in slaughterhouse workers in the Paraná State, Brazil. Rev Inst Med Trop São Paulo 48:135-140.

Hauser U, Lenhert G, Wilske B (1999) Validity of Interpretation Criteria for Standardized Western Blots (Immunoblots) for Serodiagnosis of Lyme Borreliosis Based on Sera Collected throughout Europe. J Clin Microbiol 37:2241-2247.

Langoni H, Souza LC, Silva AV, Cunha ELP, Silva RC (2008) Epidemiological aspects in leptospirosis. Research of antiLeptospira spp antibodies, isolation and biomolecular research in bovines, rodents and workers in rural properties from Botucatu, SP, Brazil. Bras J Vet Res Ani Sci 45:190199.

Macedo NA (1997) Aglutininas anti-Leptospira em soros humanos do Estado do Piauí, com particular referência aos aspectos ocupacionais, 1994 a 1996. Doctoral Thesis, Universidade Estadual de Londrina, Londrina, $125 \mathrm{pp}$.

Moura APBL, Mota RA, Silva LBG, Santos Filho AS, Coelho RMS, Lima ET (2000) Recuperação de Brucella abortus do leite in natura procedente de vacas soropositivas dos municípios de Pedra e Venturosa-PE. Rev Hig Alimentar 14:7277.

Myers D (1985) Leptospirosis: Manual de Métodos Para el Diagnostico de Laboratório (Nota técnica 30). Centro Panamericano de Zoonoses, Buenos Aires, 46 pp.

Naka EM, Costa IP, Arão CAP, Soares CO, Yoshinary NH (2008) Pesquisa de anticorpos anti-Borrelia e anti-Babesia em soro de crianças com manifestações clínicas e epidemiologia compatíveis com a doença de Lyme-simile no Estado de Mato Grosso do Sul. Rev Bras Reumatol 48:74-85.

Quinn PJ, Markey BK, Carter ME, Donnelly WJ, Leonard FC (2005) Microbiologia Veterinária e Doenças Infecciosas. Armed, Porto Alegre, 512 pp.

Pirana S, Yoshinari NH, Bonoldi V, Silveira JAM, Bento RF (2000) Reatividade sorológica para antígenos de Borrelia 
burgdorferi, Borrelia afzelli e Borrelia garinii em portadores de paralisia facial periférica no Brasil. Rev Bras Reumatol 40:55-60.

Programa das Nações Unidas para o Desenvolvimento (2010) Atlas do Desenvolvimento Humano no Brasil. http://www.pnud.org.br/atlas/instalacao/index.php.

Ramos TRR, Junior JWP, Sobrinho PAM, Santana VLA, Guerra NR, Melo LEH, Mota RA (2008) Epidemiological aspects of on infection by Brucella abortus in risk occupational groups in the microregion of Araguaína, Tocantins. Braz $\mathrm{J}$ Infect Diseases 12:133-138.

Schwabe CW (1984) Veterinary Medicine and Human Health. 3 edition. Williams \& Wilkins, Baltimore, 680 pp.

Souza AI, Nogueira JNR, Pereira MM (2007) Anticorpos antiLeptospira em pacientes do Mato Grosso do Sul com suspeita clínica de dengue e hepatite viral. Rev Soc Bras Med Trop 40:431-435.
Wray C (1975) Survival and spread of pathogenic bacteria of veterinary importance within the environment. Vet Bull 8:543550.

Yoshinari NH, Abrão MG, Bonoldi VL, Soares CO, Madruga CR, Scofield A, Massard CL, Fonseca AH (2003) Coexistence of antibodies to tick-borne agents of babesiosis and Lyme borreliosis in patients from Cotia County, State of São Paulo, Brazil. Mem Inst Oswaldo Cruz 98:311-318.

Yoshinari NH, Spolidorio M, Bonoldi VL, Sotto M (2007) Lyme disease like syndrome associated limphocytoma: First case report in Brazil. Clinics 62:525-526.

Yshikawa MM (1996) Epidemiologia da Borreliose de Lyme em Bovinos na Região Sudeste do Brasil e Padronização do Diagnóstico Sorológico. M.Sc. Dissertation, UFRRJ, Rio de Janeiro, $51 \mathrm{pp}$.

All the content of the journal, except where otherwise noted, is licensed under a Creative Commons License CC BY-NC. 